\title{
БАГАТОВИМІРНІ ШТРИХОВІ КОДИ
}

Анотація. В роботі наведено особливості класифікації, структури, та застосування штрихових кодів, відмінності лінійних та двовимірних штрихових кодів, проведено аналіз та порівняння деяких, найбільш розповсюджених двовимірних штрихових кодів, наведено особливості застосування та перспективи подальшого розвитку тривімірних та чотиривимірних кодів. Запропоновано використання інших завадостійких кодів для корекції інформації при зчитуванні.

Ключові слова: штрихове кодування, двовимірні, тривимірні та чотиривимірні штрихові коди, матричні штрихові коди, композитні штрихові коди, сканери штрихкодів, шари даних, рівень корекції помилок.

\section{Вступ}

На сьогоднішній день офіційно існує більше 50-ти типів одновимірних (1D) і більше 70-ти двомірних (2D) штрих-кодів і їх кількість постійно збільшується. Одномірні і двомірні штрих-коди найбільш відомі і широко поширені, однак бувають і інші види штрих-коду, менш відомі.

Отже, за видами, штрих-коди поділяються на:

- Лінійні одномірні (1D) (також їх називають GS1 або RSS - цю абревіатуру намагаються не використовувати, так як є така ж з іншим значенням);

- Двовимірні (2D), в тому числі матричні і композитні;

- Особливі кольорові штрих-коди, їх відносять до розряду тривимірних (Color C Code (CCC) або 3D);

- чотиривимірних (4D);

- Композитні - розміщені поруч майже будь-який лінійний штрих-код i двомірні MicroPDF417 (композитний штрих-код тип A) або PDF417 (композитний штрих-код тип С).

Лінійні (одновимірні) - це штрих коди, що читаються в одному напрямку (зазвичай, по горизонталі). Найбільш розповсюдженний є такі лінійні символіки: EAN, UPC, Code39, Code128, Codabar, Interleaved 2 of 5. Лінійні штрих коди дозволяють кодувати невеликий об'єм інформації (до 20-30 символів - зазвичай цифр) за допомогою нескладних штрих-кодів, що читаються недорогими сканерами .

Двовимірними називаються символіки, розроблені для кодування великого обсягу інформації (до декількох сторінок тексту). Двовимірний код зчитується за допомогою спеціального сканера двомірних кодів і дозволяє швидко і безпо-

(с) Б. Ю. Жураковський, В. А. Дружинін 
милково вводити великий обсяг інформації. Розшифровка такого коду проводиться в двох вимірах (по горизонталі і по вертикалі).

Tривимірні «Color C Code» з'явилися порівняно недавно - в 2010 році. На відміну від одновимірного або двовимірного штрих-коду вони можуть містити в собі будь-яку цифрову інформацію: документи, зображення, звук, анімацію і т.д. Однак не всі кольорові штрих-коди відносяться до розряду тривимірних.

Чотиривимірні штрих-коди зустрічаються вкрай рідко, та й технології їх створення та розшифровки поки нерозповсюджені. Обсяг кодованої інформації в них може бути ще більше, ніж в тривимірних кодах, вони можуть вміщати цілі сторінки сайтів, фото, рекламні та інші відео ролики і т.д.

\section{1. Особливості штрихових кодів}

Існує багато різних типів штрих коду розроблених для оптимізації одного чи кілька критеріїв:

Висока інформаційна щзільність, або високий дозвіл. Мініатюрні типи штрих-коду можуть бути надруковані і використані на виробах, де місце для кріплення обмежено, наприклад, друковані плати.

Оптимальне розташування даних, коли можливість помилок читання практично нульова. Це дуже важливо для застосувань штрих коду в медицині.

Легкість дешифрування. Деякі типи штрихових кодів використовують технологію кодування, яка широко підтримується виробниками сканерів. Штрих коди, наприклад, що використовуються в роздрібній торгівлі, мають точно визначений зміст даних. Вони структуруються для забезпечення зручності великої кількості користувачів.

Деякі типи штрих коду розроблені з підтримкою значної кількості наборів символів, тоді як інші підтримують лише цифрові дані.

Найбільш широке розповсюдження на сьогоднішній день отримав Двовимірний код (або 2-D код) - найбільш загальне найменування для всього цього класу символік.

Назви стековая символіка (stacked symbology) або багаторядний код (multirow code) більш точно відображають сутність серії кодів, в яких дані кодуються у вигляді кількох рядків звичайних одновимірних штрих-кодів.

Назва матричний код (Matrix code) застосовується для позначення двовимірних кодів, заснованих на розташуванні чорних елементів усередині матриці. Кожен чорний елемент має однаковий розмір і позиція елемента кодує дані.

Звичайний штрихкод має "вертикальну надмірність", що означає що одна $\mathrm{i}$ та ж інформація повторюється по вертикалі. Це дійсно одновимірний штрих. Висота штрихів може бути зменшена без втрати інформації. Однак, вертикальна 
Міжвідомчий науково-технічний збірник «Адаптивні системи автоматичного управління» № 2' (33) 2018 надмірність дозволяє штрихкоду, що має дефекти друку (наприклад плями або просвіти) зберігати можливість прочитання.

Двомірний код містить інформацію як по горизонталі, так і по вертикалі. Фактично, всі алфавіти є аналог двомірного коду. Оскільки обидва напрямки містять інформацію, втрачається можливість використання вертикальної надмірності. Для запобігання втрати читабельності і забезпечення швидкості зчитування повинна використовуватися інша технологія. Боротьба 3 помилками забезпечується досить просто - большиство двомірних кодів використовують спеціальні контрольні суми, що дозволяють гарантувати достовірність інформації, що вводиться.

2-D символіки стали більш прийнятними зі збільшенням використання сканерів з лазерним променем і з приладами CCD. Тепер можна читати такі коди просто провівши або махнувши рукою зі сканером над символікою. Швидкість такого руху, дозвіл сканера і дистанція сканер-символіка залишаються такими ж критичними як і з контактними зчитувачами і одновимірними штрихкодами.

Спочатку двомірні коди розроблялися для додатків, що не дають місця, достатнього для розміщення звичайного штрихкодового ідентифікатора. Першим застосуванням для таких символів стали фасування лікарських препаратів в охороні здоров'я. Ці фасування малі за розмірами і мають мало місця для розміщення штрих-коду. Електронна промисловість також проявляє інтерес до кодів високої щільності і двомірним кодами в зв'язку зі зменшенням розмірів елементів і виробів [1].

Можливість кодування портативної бази даних зробила двомірні коди привабливими для додатків, в яких мінімізація розміру коду не є основною вимогою. Наприклад, зберігання імені, адреси та демографічної інформації на картках прямої комерційної розсилки (direct mail business reply cards). Якщо повернута картка містить тільки ідентифікатор, який використовується як ключ до бази даних, то ймовірно, що картки доведеться звіряти з величезною базою даних, що містить мільйони імен. Це зажадає великих витрат на комп'ютерну обробку та зберігання такої бази. Якщо вся важлива інформація буде надрукована одночасно $з$ печаткою пропозиції на картці, істотного збільшення витрат не відбудеться, а інформація буде швидко введена з картки в комп'ютер. Працівникові набагато зручніше зчитати двомірний штрих-код за допомогою портативного пристрою, ніж звертатися до комп'ютера, розташованого в офісі [3]. 


\section{2. Ніайбільш популярні двовимірні штрихові коди PDF 417}

Стекова символіка PDF417 була введена в 1991 році фірмою Symbol Technologies. PDF походить від скорочення Portable Data File (Портативний Файл Даних), штрихкодову символ складається з 17 модулів, кожен з яких містить 4 штриха і пробілу (звідси номер 417). Штрихкод відкритий для загального користування.

Структура коду підтримує кодування максимального числа від 1000 до 2000 символів в одному коді за інформаційної щільності від 100 до 340 символів. Кожен код містить стартову і стопову групи штрихів, що збільшують висоту штрих-коду.

Код PDF417 зчитується за допомогою спеціального лазерного або CCDсканера. Символіка штрихового коду PDF417 представляє хороші можливості для кодування призначених для користувача даних в компактному і зручному для автоматичного зчитування та вигляді. Для того, щоб забезпечити високий рівень надійності зчитування конкретного символу PDF417 сканерами штрихових кодів, при завданні його параметрів перед друком необхідно враховувати ряд рекомендацій. Розділимо їх на дві групи:

1) Рекомендації на відносні розміри елементів штрихового коду;

2) Рекомендації по вибору рівня корекції помилок.

\section{Рекомендації на віднсні розміри елементів штрихового коду.}

Кожен символ PDF417 являє собою прямокутну матрицю, складену з знаків символу, кожному з яких відповідає кодове слово - число від 0 до 928. Знак символу - це послідовність з чотирьох штрихів і чотирьох прогалин, ширини яких кратні деякій величині, званої шириною модуля або просто модулем . Ширини всіх штрихів і прогалин знака можуть бути від 1 до 6 модулів, а сукупна ширина всіх його елементів повинна дорівнювати 17 модулів.

Значення ширини модуля має бути одним і тим же для всіх знаків даного символу. Висотою модуля називається висота одного рядка символу PDF417. Всі рядки повинні мати однакову висоту. ГОСТ, що описує специфікацію символіки PDF417, рекомендує наступні співвідношення між шириною (X) і висотою (Y) модуля:

а) для символів, рівень корекції помилок в яких не менше мінімального рекомендованого (див. пункт 2):

б) для символів, рівень корекції помилок в яких менше мінімального рекомендованого:

Також бажано, щоб у всіх випадках :.

Нижче зображені три символи PDF417, в яких закодовані одні й ті ж дані, але в перших двох з них не враховані рекомендації, тому їх автоматичне зчиту- 
вання може бути ускладнене (рис.1б), в останньому символі рекомендації враховані, він добре підходить для автоматичного сканування (рис.1б):

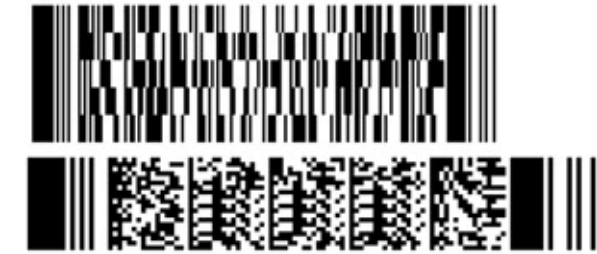

$a$

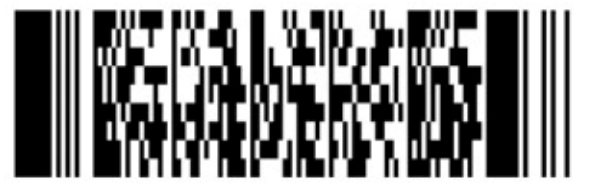

$\sigma$

Puc. 1. Три символи PDF417.

Важливо, щоб навколо символу PDF417 була залишена вільна зона - область кольору фону, вільна від зображень і написів. ГОСТ рекомендує, щоб ширина вільної зони, що оточує символ PDF417 по периметру, дорівнювала [4].

\section{Рекомендації по вибору рівня корекції помилок.}

Специфікація символіки PDF417 передбачає можливість корекції помилок або, інакше кажучи, можливість повноцінного зчитування частково пошкодженого символу. Пошкодженням ми називаємо будь-яке спотворення символу, викликане поганою якістю друку, попаданням бруду, перекриттям його іншими об'єктами, а також невдалими умовами сканування (ракурс, освітлення, відстань до сканера) i іншими явищами, через які зображення символу PDF417, що отримується сканером, буде неякісним. Корекція помилок реалізується за рахунок того, що в символі кодуються не тільки призначені для користувача дані, але ще й спеціальна послідовність кодових слів, званих кодовими словами корекції помилок.

У специфікації PDF417 передбачені 9 рівнів корекції помилок, кожному 3 яких відповідає своє кількість кодових слів корекції помилок. Якщо $s=-$ це рівень корекції помилок, то відповідне йому кількість кодових слів дорівнює

2. Створення цієї послідовності здійснює конкретний генератор символів PDF417. Рівень виправлення помилок задається користувачем. Чим вище рівень корекції, тим більші пошкодження символу допустимі при збереженні можливості зчитування. Наприклад, при з зитування стає неможливим при пошкодженні навіть одного знака символу (див. Пункт 1), тоді як рівень гарантує зчитування символу, в якому пошкоджено до 15 знаків символу, а в деяких випадках і до 30 [4].

ГОСТ містить рекомендації щодо вибору рівня корекції помилок в залежності від кількості кодових слів, що містять призначені для користувача дані. 
Таблиия 1. - Рівні коректування помилок

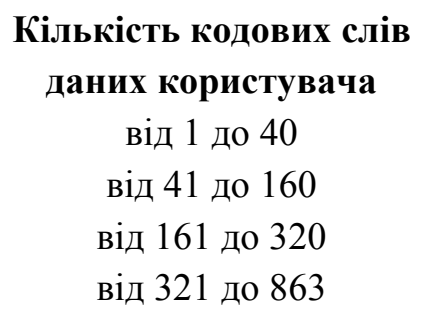

Мінімальний рівень коректування помилок

2

3

4

5

Необхідна кількість кодових слів призначених для користувача даних можна приблизно обчислити виходячи з характеру даних, дотримуючись рекомендацій:

а) якщо дані представляють собою тільки послідовність цифр, то шукана кількість кодових слів даних буде приблизно дорівнювати кількості цифр, розділеному на 2.9 ;

б) якщо дані є текстовими, то кількість кодових слів можна оцінити як кількість текстових знаків, поділене на 1.8;

в) в інших випадках приблизну кількість кодових слів даних дорівнюватиме розміру призначених для користувача даних в байтах, розділеному на 1.2.

Це лише загальні рекомендації. Більш кращим є забезпечення високої якості друку символу, в порівнянні з компенсацією низької якості друку збільшенням рівня корекції помилок.

При високу ймовірність появи в символі PDF417 пошкоджених або повністю стертих знаків символу, рівень корекції помилок може бути збільшений, в тому числі до рівня 8. Однак, в цьому випадку є ризик того, що в силу обмежень на загальна кількість кодових слів в символі PDF417, закодувати в одному символі всі призначені для користувача дані і послідовність кодових слів корекції помилок, що відповідає обраному рівню корекції, виявиться неможливим. В цьому випадку рекомендується використовувати передбачений специфікацією режим Макро PDF417, що представляє собою механізм поділу даних на блоки та подання їх у вигляді набору з декількох символів PDF417, або звернутися до інших двовимірним символіки, які дозволяють більш ефективно кодувати великі обсяги даних. Наприклад, символіка Aztec приблизно на 40\% ефективніше PDF417 кодує цифрові дані.

\section{Micro PDF 417}

Символіка штрихового коду MicroPDF417 побудована на базі символіки PDF417 і має з нею багато спільного. Основна відмінність полягає в більш компактному кодуванні даних. Специфікація символіки приведена в міжнародному стандарті ISO / IEC 24728: 2006. 
Штрих-код MicroPDF417 дозволяє закодувати в одному символі:

- до 150 байт інформації;

• до 250 літерних символів (включаючи символи табуляції, перекладу рядка і повернення каретки);

- до 366 цифр.

Крім того, є можливість розбити повідомлення на блоки, які розміщуються в різних символах MicroPDF417, але зчитуються єдиним сполученням. Для цього в стандарті передбачений механізм склейки штрих-кодів (Structured Append). Кількість штрих-кодів з яких складається повідомлення може досягати 99999.

MicroPDF417 рекомендується застосовувати, як альтернативу PDF417 при обмеженнях на розмір області друку штрих-коду.

Таке значне зменшення розмірів досягається за рахунок заміни стартових, степових і індикаторних стовпців PDF417 на більш компактні стовпчики ідентифікаторів рядків (Row Address Pattern, RAP) MicroPDF417. Сусідні рядки в цих стовпцях відрізняються лише одним модулем, завдяки чому стовпці легко локалізувати в процесі зчитування штрих-коду. Кількість рядків символу MicroPDF417 i рівень корекції помилок визначається за даними витягнутих 3 двох стовпців ідентифікаторів рядків. Рівень виправлення помилки фіксований для кожного розміру символу. Може бути виправлено до 64\% пошкоджень. Виграш в компактності MicroPDF417 досягається за рахунок зниження надійності зчитування при пошкодженнях зображення символу.

У порівнянні з PDF417, символіка MicroPDF417 менш гнучка, і має наступні обмеження: максимальне число стовпців даних - 4, максимальне число рядків - 44. Стовпці даних MicroPDF417 формуються аналогічно PDF417. У символах, що містять три чи чотири стовпці даних, $€$ центральний стовпець ідентифікаторів рядків (рис. 2).
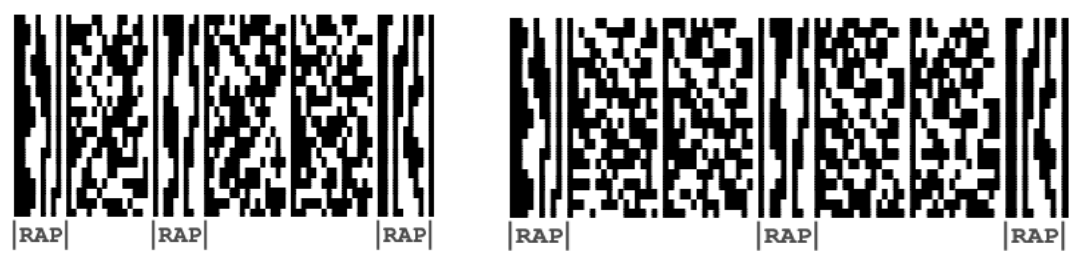

Puc. 2. Штрих-коди MicroPDF417

3 центральним стовпчиком ідентифікаторів рядків

PDF417 i MicroPDF417 теоретично можливо зчитати лазерним сканером, але на практиці дуже часто, через ігнорування рекомендацій до розмірів і друку символів штрих-коду, зробити це виходить тільки за допомогою image сканера. Рекомендацій стандарту потрібно дотримуватися, щоб забезпечити надійне зчитування штрих-кодів сканерами різних виробників. 


\section{Aztec Code}

Aztec Code введений Енді Лонакром (Andy Longacre) 3 фірми Welch Allyn Inc. в 1995 році і відкритий для загального використання. Aztec Code розроблений для легкої друку і легкої розшифровки. Штрихкод являє собою квадратну матрицю 3 концентричними квадратами в центрі, які служать для визначення позиції коду щодо сканера і мірної лінійкою по краю коду.

Тип штрих-кодів Aztec $є$ представником сімейства двомірних матричних штрих-кодів, і тому для нього справедливо все сказане вище. Зображення такого штрих-коду $є$ квадратною монохромну матрицю, складену 3 темних і світлих модулів, в центрі якої знаходиться набір квадратних концентричних кілець[5].

Найменший штрихкод Aztec має площу 15x15 модулів, найбільший 151x151. Мінімальний код Aztec кодує 13 цифр або 12 букв, а максимальний 3832 цифри або 3067 букв або 1914 байт даних. Символіка не вимагає вільної зони навколо штрих-коду. Існують 32 градації розміру коду 3 можливістю вибіркової інсталяції захисту від помилок за методом Ріда-Соломона (ReedSolomon) від 5\% до 95\% від області коду. Рекомендований рівень - 23\% ємності коду плюс 3 кодових слова.

Кодуються всі 8-бітові значення. Величини 0 - 127 представляються у вигляді набору символів ASCII, значення 128-255 представляються як ISO 88591, Latin Alphabet No.1. Крім даних можна закодувати два службових символу: FNC1 для сумісності 3 деякими існуючими додатками i ECI (escapeпослідовність) для стандартизованої кодування повідомлень.

Особливості Aztec:

- Розмір від 15х15 до 151х151 модулів;

- Чітка структура штрих-коду Aztec дозволяє відмовитися від вільної зони (чистої області навколо штрихового коду). Він може бути розташований впритул до тексту, іншим штрих-кодами і т.п .;

- Сканери VMC зчитують штрих-коди типу Aztec повернені під довільним кутом, в дзеркальному відображенні або інвертовані за кольором;

- Обсяг інформації, що кодується в одному штрих-коді: від 6 довільних байт (або 12 букв/13 цифр) до 1914 довільних байт (або 3067 букв / 3832 цифр). Значення вказані для рекомендованого стандартом рівня корекції помилок;

- Система корекції помилок призначена для збереження цілісності даних при пошкодженні штрих-коду. Рівень виправлення помилки користувач може задавати самостійно, виходячи з передбачуваних умов застосування штрихового коду. Зокрема, стандарт Aztec дозволяє створити штрих код, який буде зчитуватися при пошкодженні до 90\% його площі (за умови збереження ключових елементів його структури); 
- Структурне з'єднання дозволяє розподіляти інформацію на кілька штрихкодів (до 26-ти), що може бути корисно при розміщенні штрих-кодів в умовах обмежень на місце розташування і розміри (наприклад, іноді зручніше розташувати поруч кілька невеликих штрих-кодів, ніж один великий ). Також структурне з'єднання може використовуватися для кодування великих обсягів інформації, що не вміщується в одиночний штрих-код;

- Можливість кодувати довільні 8-ми бітові послідовності, наприклад, літери різних алфавітів і будь-які дані в призначеному для користувача форматі; Підтримка настроювальних символів, застосовуваних для настройки сканера за допомогою штрих-коду;

- Підтримка рун - невеликих (11х11 модулів) штрих-кодів, що містять один байт інформації;

- Підтримка функціонального коду 1 (FNC1);

- Формат Aztec відкритий для загального користування.

Впровадження штрих-кодів Aztec:

- Ряд транспортних компаній, що здійснюють авіа- та залізничні перевезення, розміщують штрих-код Aztec на своїх квитках і посадочних талонах. Існують і повністю безпаперові схеми, коли квитком є штрих-код, який пасажир отримує через Інтернет, і виводить на екран свого мобільного телефону;

- Польські реєстраційні документи на автомобіль містять штрих-код Aztec;

- Банківські документи ряду банків містять штрих-код Aztec, що містить всю інформацію документа. Таким чином, при необхідності введення даних в деяку автоматизовану систему, оператор може просто сканувати штрих-код, а не набирати все дані на клавіатурі [2].

\section{Data Matrix}

Data Matrix від фірми CiMatrix $\epsilon$ двомірний код, розроблений для розміщення великого обсягу інформації на обмеженій площі поверхні. Був розроблений в 1991 році і описаний в міжнародному стандарті ISO/IEC 16022: 2006.

Штрихкод Data Matrix може зберігати від одного до 500 символів. Код може масштабуватися від 1-мм щільності до 14-дюймової площі. Це означає, що код Data Matrix має теоретичну максимальну щільність 500 мільйонів символів на дюйм. На практиці щільність, звичайно, обмежується роздільною здатністю друкуючих пристроїв і сканерів [3].

Дані, що кодуються розташовуються усередині прямокутного шаблона пошуку символіки, який являє собою L-подібний куточок і набір чергуються чорних і білих модулів по периметру символа. Алгоритми зчитування Data Matrix спочатку виявляють шаблон пошуку, а потім на підставі його здійснюють деко- 
дування. Невеликі пошкодження або примикання до шаблону пошуку елементів, що не відносяться до штрих-коду призводять до неможливості декодування Data Matrix.

Data Matrix, як i інші 2D штрих-коди, має надлишкову структуру, що дозволяє декодувати дані при частковому пошкодженні символу. Істотний вплив на розробку стандарту символіки Data Matrix надав попередній йому багатостроковий штрих-код PDF-417. Структура кодування даних дуже схожа з PDF-417. Ці дві символіки дозволяють більш ефективно кодувати невеликого розміру цифрові послідовності ніж літеро-цифрові. Нижче по тексту порівняння стандарту Data Matrix буде проводиться з стандартом Aztec, тому що Aztec є новішим i продуманим 2D штрих-кодом, розробленим з урахуванням успіхів і невдач всіх попередніх символік [6].

Найсуттєвішою перевагою Data Matrix в порівнянні 3 іншими 2D штрихкодами, які широко використовуються, є той факт, що Data Matrix дозволяє на мінімально можливій площі закодувати невеликі послідовності даних. Для порівняння, якщо необхідно закодувати 6 цифр, то Data Matrix штрих-код вийде розміром всього 10х10 модулів, а Aztec - 15х15 модулів. Перевага Data Matrix втрачається при збільшенні обсягу кодируемой інформації до 72 цифр (розмір штрих-коду - 24х24 модуля). При розмірах символу 132x132 модуля в штрихкоді Data Matrix можливо розмістити 2608 цифр, в той час як в Aztec аналогічного розміру увійде майже 3000 цифр. На літеро-цифрових даних Data Matrix менш ефективний і вже на стрічках в 10 символів займає стільки ж площі скільки i Aztec. Виграш по площі при невеликих обсягах кодованих даних пояснюється тим, що в штрих-коді Data Matrix міститься дуже мало службової інформації, яка описує розміри і структуру даних штрихового коду, що негативно позначається на надійності зчитування Data Matrix. Програш Data Matrix при кодуванні великих обсягів даних пояснюється перш за все зростанням розміру шаблону пошуку символу, який збільшується прямо пропорційно периметру символу (у Aztec шаблон пошуку у великих штрих-кодів не змінюється).

Примітним є той факт, що стандарт Data Matrix допускає використання не тільки квадратних, а й прямокутних штрих-кодів, що в різних ситуаціях дозволяє більш ефективно використовувати доступну площу для розміщення символу. Стандарт Aztec для більш ефективного використання площі передбачає розбиття блоку даних на кілька символів штрих-коду з їх подальшою склеюванням. Стандарт Data Matrix так само дозволяє розбити блок даних між символами, а потім склеїти його після зчитування, але реалізація цієї склейки не настільки гнучка як в Aztec i, мабуть тому, практично не використовується. 
Міжвідомчий науково-технічний збірник «Адаптивні системи автоматичного управління» № 2' (33) 2018

Код має кілька інших цікавих особливостей. Оскільки інформація кодується абсолютною позицією елемента в середині коду, тобто позицією щодо меж коду, код не так чутливий до дефектів друку, як традиційний штрихкод. Схема кодування має високий рівень надмірності, дані роззосереджені в середині штрихкодового символу. Це дозволяє зберігати можливість прочитання коду при його частковому пошкодженні або втраті частини коду. Кожен код має вимірювальні лінійки, які виглядають як суцільна лінія по одному краю символу і рівномірно розташовані квадратні точки однакового розміру по іншому краю. Ці лінійки використовуються для визначення орієнтації і щільності коду.

Існують два основних набору символів. Вони використовують згорткове кодування для корекції помилок, яке використовувалося в перших версіях коду Datamatrix, ці версії описані як ECC-000 .. ЕСС-140. Другий набір описаний як ЕСС-200 і використовує метод корекції помилок за допомогою клда РідаСоломона (Reed-Solomon). Символи ЕCC-000 .. 140 завжди мають непарну кількість модулів по кожній стороні квадрата. Символи ЕСС-200 завжди містять парне число елементів 3 кожної зі сторін. Максимальна ємність символу ЕСС200 становить 3116 цифр або 2335 букв в символі, що складається 3144 модулів.

Найбільш популярними застосуваннями для Datamatrix $є$ маркування невеликих предметів, таких як електронні елементи і друковані плати електронних приладів. Ці додатки використовують здатність Datamatrix розмістити приблизно 50 символів в коді розміром 3 мм і той факт, що код може бути прочитаний при 20-відсоткової контрастності друку.

Код читається ПЗС-камерою або ПЗС-сканером. Символи площею від 1/8 дюйма до 7 дюйма може бути прочитаний з відстані від контакту до 36 дймов. Звичайна швидкість читання складає 5 кодів в секунду.

Отже, основна перевага використання кодування Data Matrix - компактність при кодуванні невеликих обсягів інформації (до 10 символів). Ця перевага пояснює популярність символіки в таких сферах застосування як [3]:

- медична промисловість;

- поштові перевезення;

- електронна промисловість;

- автомобілебудування;

- харчова промисловість;

- авіакосмічна та оборонна промисловість;

- енергетичне машинобудування. 


\section{QR Code}

При розробці двомірного матричного штрих-коду фірми Denso особливу увагу було приділено швидкості зчитування / декодування. Представники компанії стверджують, що їм вдалося досягти на порядок вищого швидкодії - 30 етикеток в секунду (кожна ємністю 100 символів) проти максимум 3 етикеток в секунду (такий же ємності) в кодуванні Data Matrix або PDF417. Секрет полягає в застосуванні комбінованого методу: зчитування відбувається відразу в усіх напрямках, а прискорити процедуру декодування допомагають спеціальні детектори положення (вкладені квадрати, розташовані в трьох кутах етикетки). Завдяки цим піктограмам сканер легко і швидко розбирається як в розмірі коду, так і в орієнтації етикетки на площині [3].

Специфікація QR Code знаходиться в стані розвитку, але судити про основні характеристики коду можна, наприклад, за варіантом QR Code Model 2. Цей варіант припускає наступну максимальну ємність коду (в залежності від типу даних): 7089 цифр, 4296 букв і цифр, 2953 двійкових символів (8-бітних) або 1817 символів японської мови в кодуванні Каnji-Kana. Допускається кодування суміші даних різних типів. Дані в QR Code представляються сукупністю чорних i білих точок, кожна з яких трактується як одиниця даних, або модуль. Розмір коду варіюється від 21х21 до 177х177 модулів (крок збільшення кратний 4) [2].

Основна перевага QR-коду - це легке розпізнавання скануючим обладнанням, що дає можливість використання в торгівлі, виробництві, логістиці.

Існує чотири основних кодування QR-кодів:

- Цифрова: 10 біт на три цифри, до 7089 цифр.

- Алфавітно-цифрова: підтримуються 10 цифр, літери від А до Z і кілька спецсимволов. 11 біт на два символу, до 4296 символів

- байтовими: дані в будь-якої зручної кодуванні (за замовчуванням ISO 8859-1), до 2953 байт.

- Кандзі: 13 біт на ієрогліф, до 1817 ієрогліфів.

В таблиці 2 наведено порівняння чотирьох двовимірних штрихових кодів PDF417, DataMatrix, QR-код, Aztec Code. 


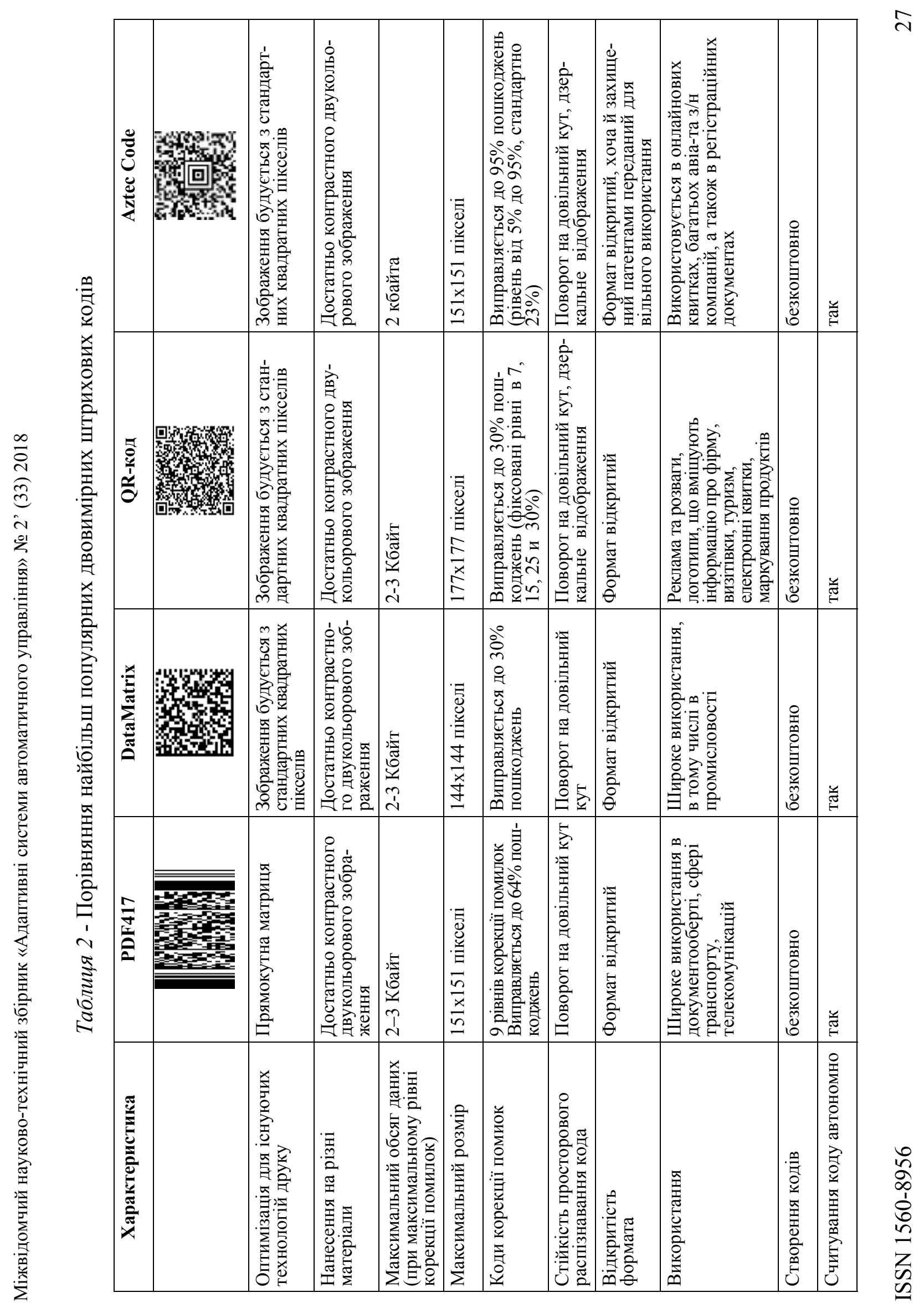




\section{3. Порівняльна оцінка завадостійких кодів, які використовуються для виправлення помилок при передачі інформації}

Серед завадостійких кодів спробуємо обрати код, при використанні якого, підвищаться показники якості штрихового коду, а саме обсяг корисної інформації. При виборі коду, необхідно, щоб загальна кількість символів була приблизно однакова. Потім, порівнявши надмірності кодів 3 надмірністю коду Ріда-Соломона, а саме він використовується, як завадостійкий код при кодуванні інформації в усіх розглянутих двовимірних штрихових кодах, спробуємо визначити оптимальний завдостійкий код. Для порівняння використаємо циклічні коди, до яких належить код Ріда-Соломона, а саме код Файра та БЧХ. Довжину комбінації кодів БЧХ можна визначити так:

$$
n=2^{h}-1 \text { або } n=\frac{2^{h}-1}{g}
$$

де $h>0$ - ціле число; $g$ - непарне додатне число, при діленні на яке $n$ стає непарним числом. Таким чином, довжина $n$ може мати тільки непарну кількість елементів.

Кількість перевірних елементів коду визначається виразом [7]:

$$
r \leq \frac{h(d-1)}{2}=\left[\log _{2}(n+1)\right] \frac{d-1}{2},
$$

А кількість інформаційних елементів:

$$
k \geq\left(2^{h}-1\right)-\frac{h(d-1)}{2} \quad \text { або } k=n-r,
$$

Твірний поліном коду Файра визначається виразом

$$
P_{\phi}(x)=P(x)\left(x^{c}+1\right),
$$

де $P(x)$ - незвідний поліном степеня $l$, що належить $h ; c$ - просте число, яке не повинно ділитися на $h$ без остачі.

Поліном $P(x)$ має деякий ступінь $h$, якщо $h$ - найменше додатне число таке, що двочлен $x^{h}+1$ ділиться на $P(x)$ без остачі. Для будь-якого існує принаймні один незвідний поліном $P(x)$ степеня $l$, який належить числу

$$
n=2^{l}-1
$$

Довжина коду Файра визначається виразом

$$
n=H C K(c, h),
$$

тобто $є$ НСК чисел $h$ та $h$, тому що тільки в цьому разі двочлен $x^{h}+1$ буде ділитися на поліном $P(x)$ без остачі. 
Міжвідомчий науково-технічний збірник «Адаптивні системи автоматичного управління» № 2’ (33) 2018

Кількість перевірних елементів цього коду визначається:

$$
r=c+1,
$$

а інформаційних:

$$
k=n-c-l,
$$

Для коду Ріда Соломона поліном, що породжує, а також виправляє $s$ помилок, повинен мати $2 s$ коренів: $\left\{a^{j_{0}}, a^{j_{0}+1}, a^{j_{0}+2}, \ldots, a^{j_{0}+2 s-1}\right\}$, де $j_{0}$ - конструктивний параметр. Як правило, $j_{0}$ вибирають рівним 1. Тоді безліч коренів полінома приймає вигляд $\left\{a, a^{2}, a^{3}, \ldots, a^{2 s}\right\}$.

Для коду Ріда-Соломона, що виправляє $s$ помилок, поліном, що породжує, має наступний вигляд:

$$
R S(X)=(X-a)\left(X-a^{2}\right)\left(X-a^{3}\right) \ldots\left(X-a^{2 s}\right)
$$

При такому уявленні поліном, що породжує, має безліч коренів $\left\{a, a^{2}, a^{3}\right.$, $\left.\ldots, a^{2 s}\right\}$

Довжина кодової комбінації над полем $G F(q)$ :

$$
N=q-1
$$

де $q$ - основа (алфавіт) коду.

Кількість перевірних елементів цього коду визначається:

$$
r=2 v_{\text {вп }}=n-k .
$$

де $v_{\text {вп }}$-кількість виправлених помилок.

а інформаційних:

$$
k=n-r .
$$

Для порівняння кодів оберемо приблизно однакову довжину кодових комбінаціїй та обчислимо надмірність кодів при мінімальних кодових відстанях $d=5,7,11,15$.

Кращим буде той код, який має меншу кількість $r$ надмірних елементів у блоці $(r=n-k)$, а тому й меншу надмірність $R=r / n$.

За допомогою програми визначимо надмірність для кодів БЧХ, Файра i Ріда-Соломона.

Отримані результати занесемо в таблицю 3.

Таблиия 3. -Залежність коефіцієнта надмірності коду від кодової відстані

\begin{tabular}{|c|c|c|c|}
\hline \multirow{2}{*}{ Кодова відстань, $\mathbf{d}$} & \multicolumn{3}{|c|}{ Коефіціснт надмірності, $\mathbf{R}$} \\
\cline { 2 - 4 } & $\mathbf{6 Ч X}$ & Файра & Ріда-Соломона \\
\hline 5 & 0,23 & 0,19 & 0,22 \\
\hline 7 & 0,22 & 0,1 & 0,126 \\
\hline 11 & 0,2 & 0,05 & 0,078 \\
\hline 21 & 0,188 & 0,024 & 0,047 \\
\hline
\end{tabular}


Зобразимо дану залежність на рисунку 3 :

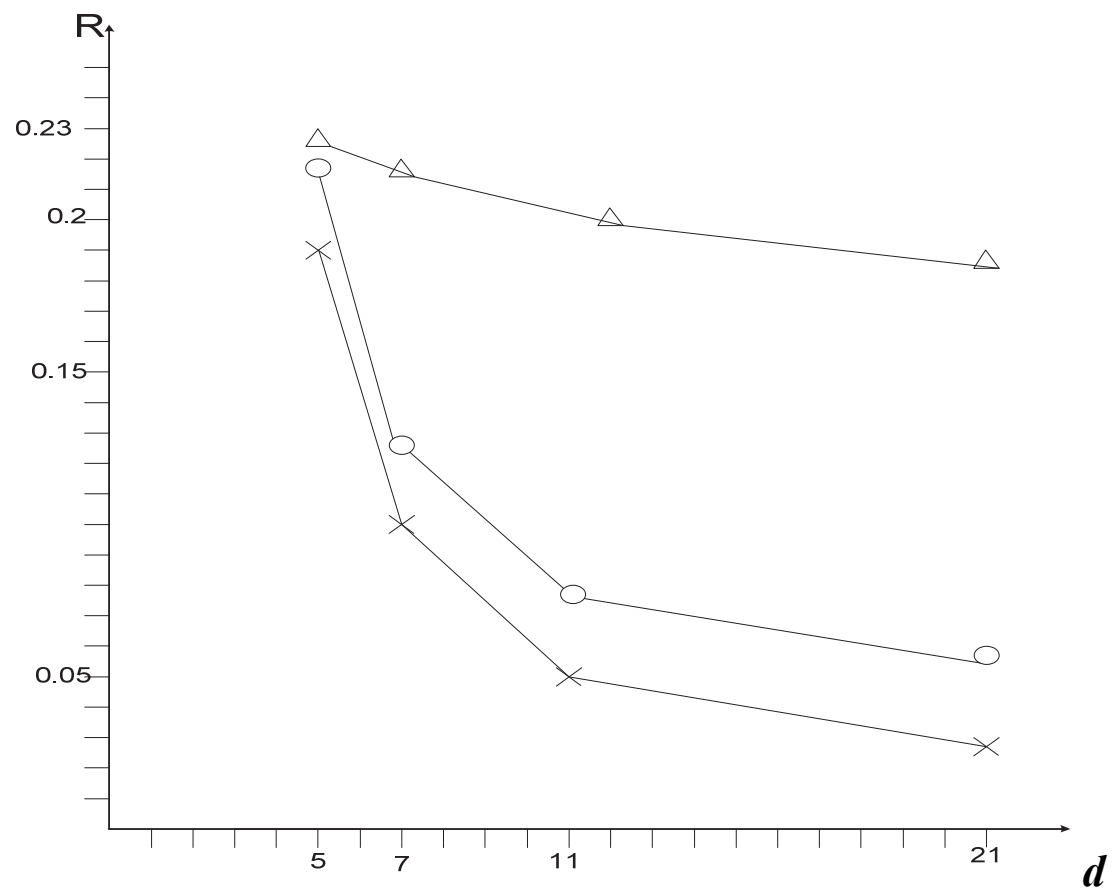

- Код БЧХ

- Код Файра

- Код Ріда-Соломона

Puc. 3. Залежність коефіцієнта надмірності коду від кодової відстані

Проаналізувавши отримані дані можна зробити висновок, що найменший коефіцієнт надмірності має код Файра, адже цей код коротший від коду БЧХ та коду Ріда-Соломона. Таким чином найменшу надмірність повідомлення забезпечить код Файра. Це дасть можливість записати більшу кількість інформації користувача, майже при такій ж ступені корекції помилок, як й при використанні коду Ріда-Соломона.

\section{Висновки}

1. В роботі наведено особливості класифікації, структури, та застосування штрихових кодів.

2. Розгляуто основні відмінності лінійних та двовимірних штрихових кодів, Наведено особливості застосування та перспективи подальшого розвитку тривімірних та чотиривимірних кодів.

3. Проведено аналіз та порівняння найбільш розповсюджених двовимірних штрихових кодів таких як: PDF 417, Aztec Code, Data Matrix, QR-код. Можливо використання штрихового кодування з іншими завадостійкими кодами для запобігання 
виникнення помилок при зчитуванні наприклад, код Файра, який забезпечує майже такій ж ступені корекції помилок, як й при використанні коду Ріда-Соломона, але дасть можливість записати більшу кількість інформації користувача.

\section{Список використаних джерел}

1. Жураковський Б.Ю. Сфери застосування двовимірних штрихових кодів / Жураковський Б.Ю., Довженко Н.М. // Системи управління, навігації та зв’язку № 2(38), 2016. - С.83-87.

2. Жураковський Б.Ю. Особливості застосування QR-кодування в телекмунікаційній мережі України / Жураковський Б.Ю., Довженко Н.М. // Науково-технічна конференція «Актуальні проблеми розвитку науки і техніки», ДУТ, м. Київ. - 22.10.2015. с. 18-21.

3. QR-код та Data Matrix [електронний ресурс]. - режим доступу до матеріалів статті: https://mybiblioteka.su/tom2/3-80575.html

4. Виды и типы штрихкодов [електронний ресурс]. - режим доступу до матеріалів статті: https://kkm74.ru/articles/vidy_i_tipy_shtrih_kodov/.

5. Жураковський Б.Ю. Порівняльний аналіз формування та застосування двомірних штрих-кодів для передачі даних / Жураковський Б.Ю., Довженко Н.М. // Системи управління, навігації та зв’язку № 2(34), 2015. - С.68-70.

6. Астафьева Е. История появления и развития популярных 2D штрихкодов [електронний ресурс]. - режим доступу до матеріалів статті: https://idexpert.ru/reviews/13658/

7. Жураковський Б.Ю. Використання методів адаптивного кодування для каналів з параметрами, що змінюються / Жураковський Б.Ю. // Вісник ДУІКТ № 5(2), 2007. - С.199-202. 